\title{
RECENVED
}

OCT 101995

OSTH

\section{The Effect of Dilution on the Gas-Retention Behavior of Tank 241-SY-101, Waste}

P. R.Bredt

S. M. Tingey

E. H. Shade

September 1995

Preparèd for

the U.S. Department of Energy

Contract DE-AC06-76'RLO 1830

Pacific Northwest Laboratory

Operated for the U.S. Department of Energy

by Battelle Memorial Institute

9. Battelle 


\section{DíSCLAIMER}

This report was prepared as an account of work sponsored by an agency of the United States Government: Neither the United States Government nór any agency thereof, nor Battelle Memórial Institute, nor any of their emploýees, makes any warranty, expressed or implied, or àssumes any legal liability or responsibility for theaccuracy, completeness, or usefulness of any information, apparatus, product, or process disclosed, or represents that its use would not infringe privátely owned rights: Reference herein to any spècific commerçial product, process, or service by trade name, trademark, manufacturer, or otherwise does nót necessarily constitúte or imply its'endorsement; recommendation, or favoring by the United States Government or any agency thereof, ór Battelle Memórial Institute. The views and iopinions of authors expressed herein do not necessarily state or reflect those of the United States Government or any agency thereof.

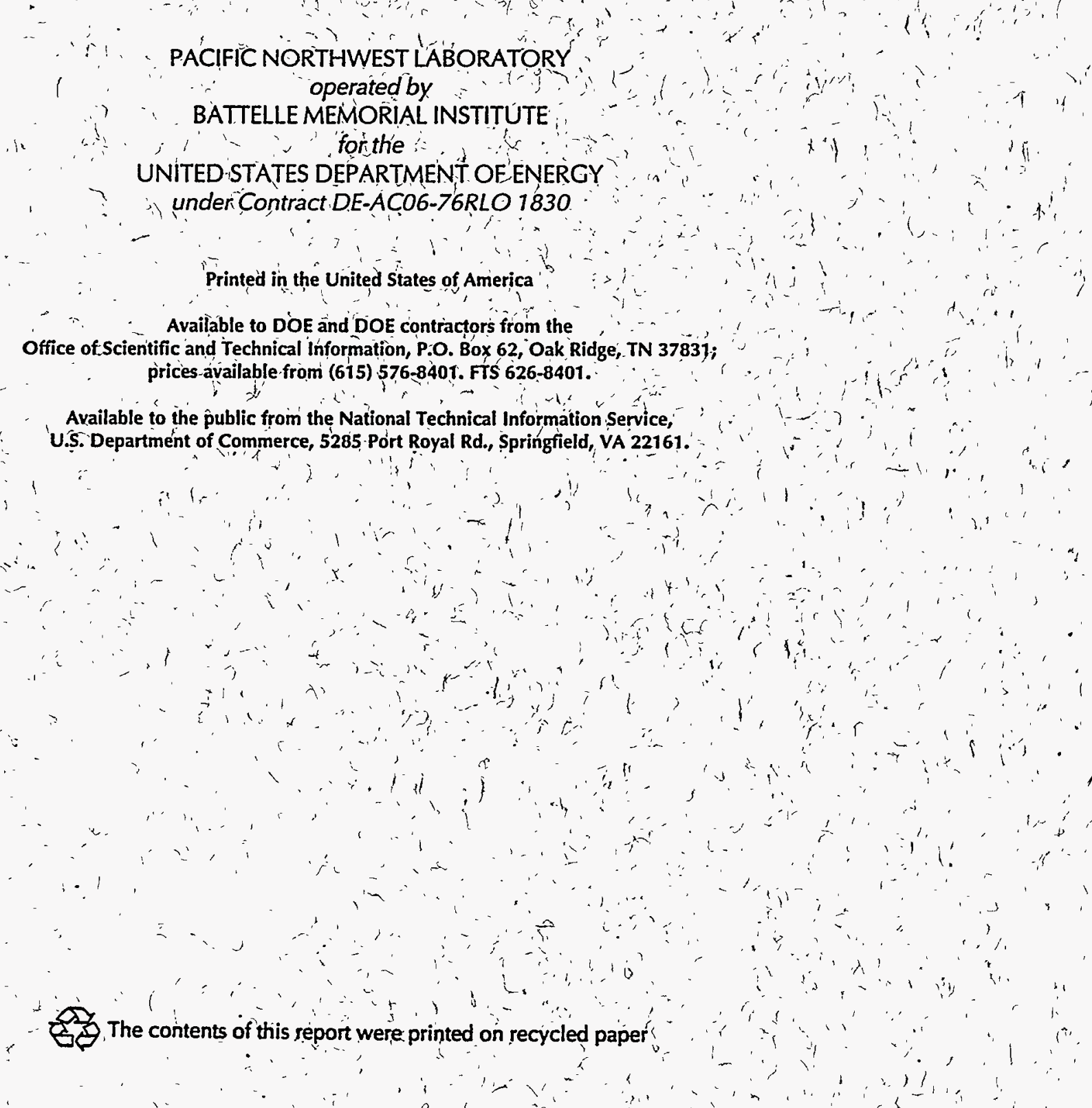




\section{DISCLAIMER}

Portions of this document may be illegible in electronic image products. Images are produced from the best available original document. 


\section{The Effect of Dilution on the Gas-Retention Behavior of Tank 241-SY-101 Waste}

P. R. Bredt

S. M. Tingey

E. H. Shade

September 1995

Prepared for

the U.S. Department of Energy

under Contract DE-AC06-76RLO 1830

Pacific Northwest Laboratory

Richland, Washington 99352 


\section{Executive Summary}

The effect of dilution on gas retention in waste from Tank 241-SY-101 was investigated. A composite sample was prepared from material collected during the Window " $C$ " and Window " $E$ " sampling events. The composite contained material from both the convective and nonconvective layer in the proportions existing in the tank. Operation of the mixer pump in Tank 241-SY-101 has homogenized the tank material, and dilution of the current waste would require additional mixing; therefore, no attempt was made to use unhomogenized tank waste to prepare the composite. The composite was diluted with $2 \mathrm{M} \mathrm{NaOH}$ at ratios of $0.5: 1,0.75: 1,1: 1$, and $3: 1$ per volume ( $2 \mathrm{M} \mathrm{NaOH}: \operatorname{tank}$ waste).

The diluted samples and composite were allowed to settle in duplicate for 23 days while the volume of settled solids was monitored. The volume percent settled solids stabilized by the fifteenth day of settling for all dilutions.

The diluted samples and composite were exposed to a $500 \mathrm{Ci}{ }^{137} \mathrm{Cs}$ source for 27 days while the volume of settled solids, volume of total waste, and volume of gas in the head space were monitored. During the first four days of irradiation, additional settling was observed in all of the 0.5:1, 0.75:1, and 1:1 diluted samples and in one each of the composite and 3:1 samples.

Volume measurements showed no significant gas retention in the settled solids over the 27-day irradiation period. Gas generation was greatest for the $0.5: 1$ samples followed by the $0.75: 1$ samples and then the whole tank composite. The volume of gas generated by the 1:1 and 3:1 samples was below that produced by the composite.

After 28 days of irradiation, a vacuum was applied to the head space of the sample vessels. The drop in pressure caused retained bubbles to expand and could also have caused other gases in solution to be drawn into bubbles. The composite and $0.5: 1$ and $0.75: 1$ samples experienced gas retention and events similar to an actual tank rollover. The 1:1 and 3:1 samples did not experience rollovers or gas retention. These results support the recommendation that a 1:1 dilution of Tank 241-SY-101 waste will mitigate hazardous-gas-release-event behavior (Hudson et al. 1995). 


\section{Contents}

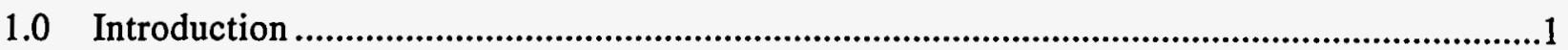

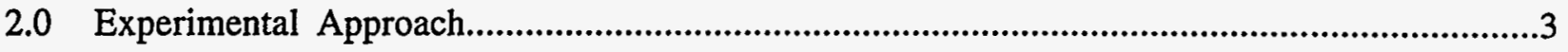

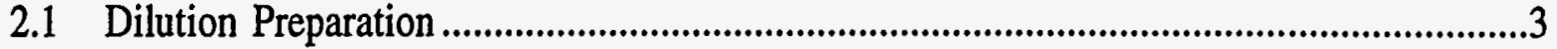

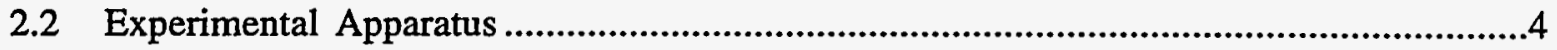

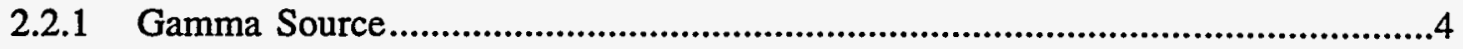

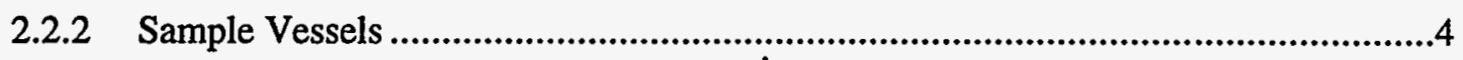

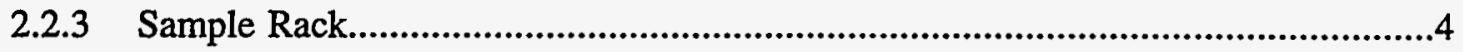

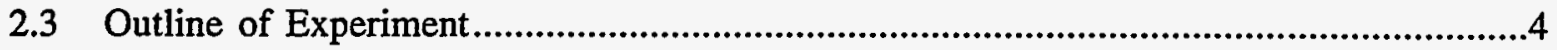

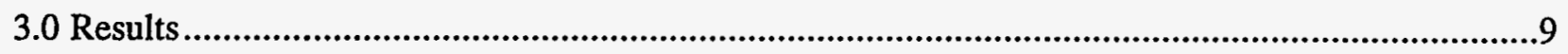

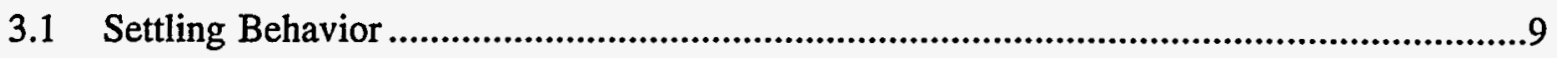

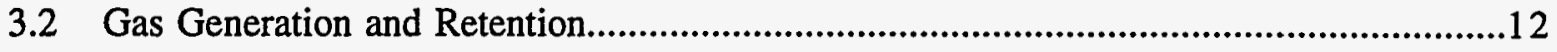

3.3 Applying Vacuum to the Sample Vessels.....................................................................13

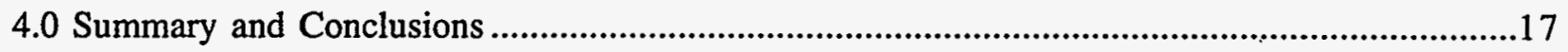

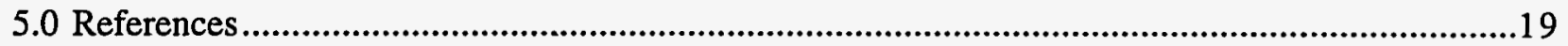

\section{Tables}

2.1 Material Used to Prepare Tank Composite ............................................................................3

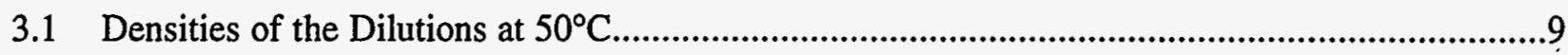

3.2 Volume Percent Settled Solids at Day 23 and at End of Day 24.....................................11

3.3 Total Waste Volumes from the Irradiation Phase of Testing ..................................................12

\section{Figures}

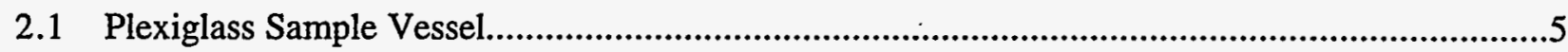

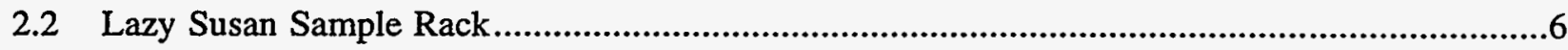

3.1 Gas-Retention Experiment in the Hot Cell...........................................................................10

3.2 Volume Percent Settled Solids During the Settling and Irradiation Period..............................11

3.3 Gas Generation Plotted as Volume Change in the Head Space of the Sample Vessels ..............14 



\subsection{Introduction}

Twenty-five of the 177 underground waste storage tanks on the Hanford Site have been placed on the Flammable Gas watch list. These 25 tanks, containing high-level waste generated during plutonium and uranium processing, have been identified as potentially capable of accumulating flammable gases above the lower flammability limit (Babad et al. 1991). In the case of Tank 241SY-101 (to be referred to as SY-101), it has been proposed that diluting the tank waste may mitigate this hazard (Hudson et al. 1995; Stewart et al. 1994). This study determined the effect of dilution on the ability of waste from SY-101 to accumulate gas. Pacific Northwest Laboratory (PNL) ${ }^{(a)}$ contracted with Westinghouse Hanford Company to perform this work.

Before installing the mixer pump in 1993, the waste in SY-101 had stratified into three layersnonconvective, convective, and crust. The nonconvective layer extended from the bottom of the tank to a height of approximately $391 \mathrm{~cm}$. The convective layer extended from $391 \mathrm{~cm}$ to $919 \mathrm{~cm}$ and the crust, located on the top of the convective layer, had an average thickness of $100 \mathrm{~cm}$. The nonconvective layer was distinguished by a high solids content $(<32 \%$ water by weight), shear . strength (approximately 50,000 dynes $\left./ \mathrm{cm}^{2}\right)$, viscosity $\left(>10,000 \mathrm{cP}\right.$ at shear rates below $\left.500 \mathrm{~s}^{-1}\right)$, and density $\left(1.68 \mathrm{~g} / \mathrm{mL}\right.$ at $\left.32^{\circ} \mathrm{C}\right)$. These properties were lower in the convective layer ( $>35 \%$ water by weight, $<60 \mathrm{cP},<1.53 \mathrm{~g} / \mathrm{mL}$ at $32^{\circ} \mathrm{C}$ ). The crust had a high solids content ( $14.3 \%$ water by weight), shear strength $\left(>250,000\right.$ dynes $\left./ \mathrm{cm}^{2}\right)$, and density $(1.77 \mathrm{~g} / \mathrm{mL})$. Since pump operation, the convective and nonconvective layers have been effectively homogenized, leaving only a mixed slurry layer and a crust (Stewart et al. 1994). If pumping operations were discontinued, the waste could return to the original three-layer stratification.

Gas generated in the waste is a result of both chemical and radiochemical decomposition. Before pump operations, gases were retained in the nonconvective layer by attachment to the solid particles. This gas-slurry mixture was held together by cohesive forces. When the buoyancy of the mixture was great enough to overcome the cohesive forces, the mixture would rise to the surface and release the retained gas. Agitation of the nonconvective layer resulting from this rise would break loose more buoyant material that would also rise. This rising of the gas-slurry mixture would continue until a large portion of the nonconvective layer had released its trapped gas. This tank-wide rise of the nonconvective layer was referred to as a "rollover" or "gas release event"(GRE) (Allemann et al. 1993).

While diluting the tank waste has been considered a potential mitigation strategy for some time, insufficient direct experimental evidence has existed to indicate the degree of dilution necessary to achieve mitigation (Stewart et al. 1994). However, the effects of dilution on several related properties, including viscosity, shear strength, solids content, and density, have recently become available (Tingey et al. 1994). These results show a significant decrease in properties related to gas retention up to dilution ratios of $1: 1$ using $2 \mathrm{M} \mathrm{NaOH}$.

While no studies have directly examined gas retention as a function of dilution, it is assumed that as these properties decrease, mitigation could be achieved in one of three ways: 1) as the shear strength and viscosity of the material is lowered, the gas bubbles would no longer be retained in the nonconvective layer, and the gas would release through the solids, 2) the density of the solids drops to a point at which neutral buoyancy is reached at low-gas content, and 3 ) the solids content drops, resulting in a lower absolute volume of retained gas. In the first case, rollover behavior is eliminated. In the last two, rollovers would still occur; however, the resulting gas concentrations in the tank head space would be below the lower flammability limit. Using these mitigation models, Hudson et al. (1995) inferred from the measured property changes that the flammable gas hazard could be mitigated with a 1:1 dilution of the waste using $2 \mathrm{M} \mathrm{NaOH}$.

(a) Pacific Northwest Laboratory is operated for the U.S. Department of Energy by Battelle Memorial Institute under Contract DE-AC06-76RLO 1830. 
The scope of this study was to experimentally determine the effects of dilution on gas retention of actual waste samples. Because operation of the mixer pump in SY-101 has homogenized the tank material and dilution of the current waste would require additional mixing, no attempt was made to use unhomogenized tank waste for this testing.

A tank composite was prepared from SY-101 material collected during the Window " $\mathrm{C}$ " and Window " $\mathrm{E}$ " sampling events. Dilutions were prepared using $2 \mathrm{M} \mathrm{NaOH}$ at ratios of $0.5: 1,0.75: 1$, 1:1, and 3:1. A $500 \mathrm{Ci}{ }^{137} \mathrm{CsCl}$ source was used to generate gas in the dilutions while the settled solids volume and total waste volumes were monitored. 


\subsection{Experimental Approach}

This section summarizes the apparatus used to assess changes in the gas-retention behavior of diluted waste samples as well as documenting the history of these samples. This work was conducted at the 325 building in the High Level Radiochemistry Facility (325A HLRF).

The goal of this work was to generate a measurable volume of gas in the waste and observe if this gas is retained in the settled slurry or lost to the head space. Two potential mechanisms for generating gas in the waste include thermal decomposition and radiolysis. Since properties related to gas retention are affected by temperature (Tingey et al. 1994), gas was generated by radiolysis. The experiment was conducted at a temperature similar to actual tank conditions, $50^{\circ} \mathrm{C}$.

\subsection{Dilution Preparation}

A tank composite was prepared for this testing using archived material from the May 1991 (Window "C") and December 1991 (Window " $\mathrm{E}$ ) sampling events (Herting et al. 1992a; Herting et al. 1992b). Table 2.1 lists the material used. Twenty-five grams of deionized water were added to the composite to make up for water lost during storage. The composite was gently stirred with a spatula to homogenize. Two samples of the composite were loaded into graduated 15 -mL centrifuge cones and centrifuged for $2 \mathrm{~h}$ at $1000 \mathrm{xg}$. The density of the composite was then determined by dividing the mass by the volume. The calculated densities were $1.51 \mathrm{~g} / \mathrm{mL}$ and $1.53 \mathrm{~g} / \mathrm{mL}$, resulting in an average density for the composite of $1.52 \mathrm{~g} / \mathrm{mL}$.

Sample dilutions were prepared by adding ratios of $0.5: 1,0.75: 1,1: 1$, and 3:1 of $2 \mathrm{M} \mathrm{NaOH}$ to the composite by volume. For example, the $0.5: 1$ dilution was prepared with a known volume of waste $(Y \mathrm{~mL})$ and adding an additional $50 \%$ of that volume in $2 \mathrm{M} \mathrm{NaOH}(0.5 \mathrm{Y} \mathrm{mL})$. The diluted waste was then slowly stirred with a spatula. The samples were placed in an oven at $50^{\circ} \mathrm{C}$ for a period of 2 weeks. Every day during the first week, the samples were inverted to mix the solids and liquids. The samples were inverted twice a week for the remaining week. The samples were then removed from the oven for 1 week and left in the cell at $33^{\circ} \mathrm{C}$. The samples were returned to the oven 1 week before loading the sample vessels and inverted every other day.

Table 2.1. Material Used to Prepare Tank Composite

Sample

101-SY Solids

Window "C" Segment 22A

Window "C" Solids Composite From

Segments $16,16 \mathrm{R}$ and 18

Window "E" Segment 15

Window "C" Segment 4

Window "E" Segment 8

Window "E" Segment 13

Window "E" Segment 3
Mass (g) Comments

114 Composite of nonconvective

133.07

33.78

79.63

88.15

71.72

19.37

\section{segments}

$0 \%$ dilution used in Heating and

Dilution Study (Tingey et al. 1994)

$19 \mathrm{~g}$ below archived mass

$4 \mathrm{~g}$ below archived mass

$2 \mathrm{~g}$ below archived mass 


\subsection{Experimental Apparatus}

\subsubsection{Gamma Source}

A single NORDIAN capsule was used as the ionizing radiation source for the experiment. This capsule is a singly encapsulated $\left(0.037\right.$ in. thick wall) ${ }^{137} \mathrm{CsCl}$ sources, 9.84 in. long and 0.38 in. in diameter with an activity of approximately $500 \mathrm{Ci}(\gamma=0.66 \mathrm{MeV})$ at the time of this work. To meet 325 building Safety Analysis Report requirements, a secondary 1/8-in. steel capsule was added to the primary encapsulation of approximately 0.037 in. A third jacket of approximately $1 / 16$ in. was used to prevent contamination of the source while in the HLRF.

Dose rates were taken 4 and 8 in. from the triply encapsulated source using thermoluminecent detectors (TLDs). Twenty-five TLDs were exposed to the source for $1 \mathrm{~h}$ using the sample holder described in Section 2.2.3. The TLDs were read by PNL Health Physics. Twenty TLDs exposed at four different locations, $8 \mathrm{in}$. from the source, showed a dose rate of $2.7( \pm 0.2) \mathrm{kR} / \mathrm{h}$. Five TLDs exposed at one location, $4 \mathrm{in}$. from the source, showed a dose rate of $8.2 \mathrm{kR} / \mathrm{h}$. No error associated with position can be assigned from the single location at 4 in.; however, the five TLDs had a relative error of $\pm 5 \%$.

Samples in this work were exposed 8 in. from the source through a 0.25 -in. water jacket. Correcting for the attenuation of the water, the dose rate to the samples was $2.5 \mathrm{kR} / \mathrm{h}$.

\subsubsection{Sample Vessels}

During testing, the samples were contained within graduated plexiglass vessels. Figure 2.1 shows a picture of one vessel. The vessels were fabricated with a water jacket for temperature control. The vessel lids, sealed with two silicone gaskets, were made of plexiglass and equipped with a graduated quartz manometer containing mercury. The mercury served to retain water vapor and indicate any volume changes in the system during irradiation. Ten caps were fabricated without manometers and used during the settling phase of testing. The manometers were glued to the caps using silicone rubber cement. The water jackets were connected in series to the water bath using nylon braided silicone rubber hosing.

Materials were tested for radiation durability at the 300 area gamma pit facility in the 3730 building. Materials were inspected at total doses of $10^{6} \mathrm{R}, 10^{7} \mathrm{R}$, and $10^{8} \mathrm{R}$. All materials performed acceptably up to $10^{7} \mathrm{R}$. The plexiglass and silicone hosing failed by $10^{8} \mathrm{R}$. No gas generation was detected during radiation testing of the plexiglass or silicone rubber cement.

\subsubsection{Sample Rack}

A round rack was fabricated to hold the sample vessels at a fixed distance from the source during irradiation (see Figure 2.2). The stainless steel rack was equipped with a lazy Susan to aid in sample loading and inspection. The gamma source was held vertically in the center of the rack. The rack contained 20 sample positions, 10 at 8 in. from the source and 10 at 4 in. from the source. These distances are from the center of the source to the center of the sample. During this study, all samples were placed 8 in. from the source.

\subsection{Outline of Experiment}

The samples were diluted as described in Section 2.1. The samples were loaded into the vessels in duplicate, sealed and allowed to settle undisturbed for 23 days at $50^{\circ} \mathrm{C}\left( \pm 2^{\circ} \mathrm{C}\right)$. The gamma source was then placed in the center of the rack, and the mercury manometers were installed on the vessels. The temperature of the vessels was maintained at $50^{\circ} \mathrm{C}$. The volume of the settled solids, total waste (solids and liquids), and system (solids, liquids and head space) were monitored for 27 days. Photographs and video tape recordings were made to document visual observations. 


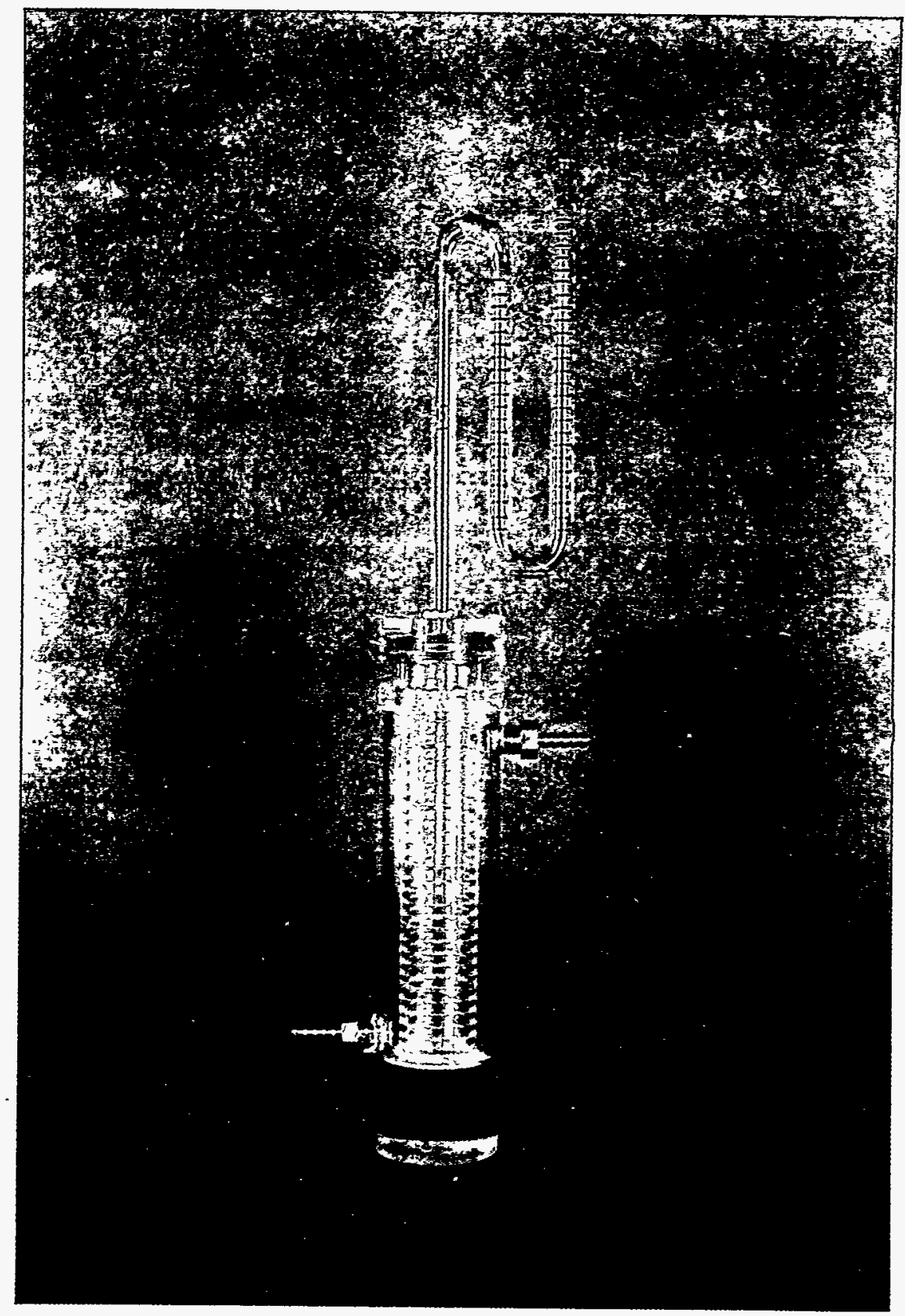

Figure 2.1. Plexiglass Sample Vessel 


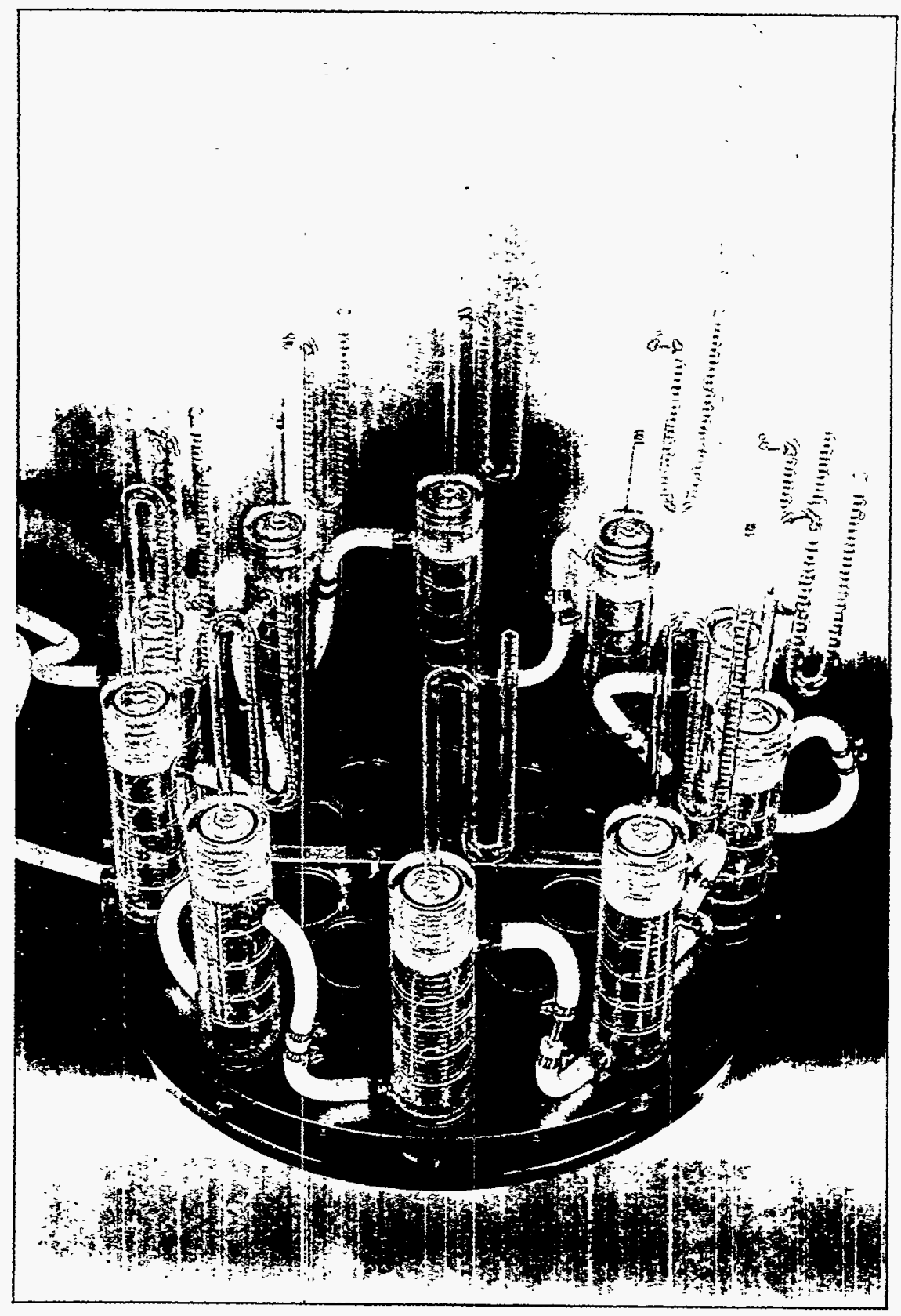

Figure 2.2. Lazy Susan Sample Rack 
Following the irradiation phase of testing, one vessel at each dilution level was attached to the facility vacuum system and pumped down to a vacuum of $\sim 22 \mathrm{In}$. of $\mathrm{Hg}$. Application of a vacuum was not in the original scope of the work, so the facility vacuum gauge was not calibrated to meet PNL QA Impact Level II requirements. Data from this gauge were used for indication only. Slurry growth and waste behavior were monitored and recorded with the video equipment.

During the irradiation phase of the experiment, measurements were taken on a daily basis, including settled solids volume, total waste volume, displacement of the mercury in the manometers, absolute pressure in the hot cell gallery, and the differential pressure between the hot cell and the gallery.

Displacement of the mercury columns, absolute pressure in the gallery, and the cell differential pressure were used to calculate the pressure in the vessels. This was combined with the increase in head space volume, measured as the displacement of the mercury, to calculate the gas generation. Gas could be either in the head space or retained in the solids. No gas bubbles were observed in the liquid.

It is possible to determine gas retention in the solids using changes in the total waste volume and changes in the settled slurry volume. Two types of bubbles have been identified as retained in the settled layer of simulated waste, dendritic and round (Gauglitz et al. 1995). Dendritic bubbles fill the space between particles and displaced the interstitial liquid. Dendritic bubble volume is measured as an increase in the total waste volume only. Round bubbles push the particles and liquid out of the way and increase the settled slurry volume and total waste volume equally. Therefore, total gas retention is measured as the change in the total waste volume. Round bubble volume is determined by the change in settled solids volume, and dendritic bubble volume is calculated by subtracting the round bubble volume from the total gas retention. Due to the minimal waste height, $\sim 10 \mathrm{~cm}$, and the scaling suggested by Gauglitz et al. (1995), it was expected that only round bubbles should form under these experimental conditions. 


\subsection{Results}

This section summarizes the effects of dilution on the gas-retention ability of SY-101 waste. A whole tank composite was studied at dilution ratios of $0: 1$ (undiluted), 0.5:1, 0.75:1, 1:1, and 3:1 using $2 \mathrm{M} \mathrm{NaOH}$. Work was conducted at $50^{\circ} \mathrm{C}$. Properties discussed in this section include settling behavior, radiolytic gas generation rates, and gas-retention behavior. Figure 3.1 shows the experimental system in use. The raw data are contained in laboratory notebook BNW-55817. The apparatus was designed to "Good Practices Standards," and work with actual tank waste was performed to Impact Level II requirements as described in PNL-MA-70.

\subsection{Settling Behavior}

A known mass of diluted sample was loaded into each of the ten sample vessels. The vessels were then capped, and the total sample volume and volume of settled solids were measured throughout the course of the experiment. The waste density was calculated by dividing the mass of the waste by the total volume. The volume used in the density calculation was measured on the first day of irradiation. The densities of the dilutions are listed in Table 3.1.

Table 3.1. Densities of the Dilutions at $50^{\circ} \mathrm{C}$

$\begin{array}{lc}\text { Dilution } & \text { Density ( } \\ 0.00: 1 & 1.60 \\ 0.50: 1 & 1.42 \\ 0.75: 1 & 1.37 \\ 1.00: 1 & 1.28 \\ 3.00: 1 & 1.23\end{array}$

The volume percent settled solids was calculated by dividing the settled solids volume by the total waste volume. The volume percent settled solids is plotted as a function of time in Figure 3.2. Volumes in the sample vessels were read to $\pm 0.51 \mathrm{~mL}$. The resulting uncertainty in the volume percent settled solids volumes varied from $\pm 1.3 \%$ for the tank composites (approximately $75 \%$ $\pm 1.3 \%$ ) to $\pm 1.0 \%$ for the $3: 1$ samples (approximately $10 \% \pm 1.0 \%$ ). The $0: 1,0.75: 1,1: 1$, and $3: 1$ diluted samples reached a stable settled solids volume within the first 10 days. The 1:1 diluted samples reached a stable volume by 15 days.

The source was installed in the rack after 23 days of settling. By the end of day 24 , the volume percent settled solids dropped in all of the $0.5: 1,0.75: 1$, and $1: 1$ samples and in one each of the $0: 1$ and 3:1 samples. The volume percent settled solids before and after the drop are listed in Table 3.2. Surface structures including cracks, bulges, and craters were observed at the solids-liquid interface following the collapses. The cause of this collapse is unclear. Surface structures and settled bed collapses have been observed in iron oxide suspensions (Glasrud et al. 1993). One possibility is that a small mechanical agitation caused by introduction of the source resulted in the disturbance of a stable structure; however, agitation of this waste form would normally be expected to loosen the fine solids, causing an initial increase in the volume percent settled solids and a clouding of the liquid phase. Another possible explanation is a drop in the zeta potential of the waste resulting from the ionizing radiation source; however, if this were the case, the percent decrease should have been more uniform. 


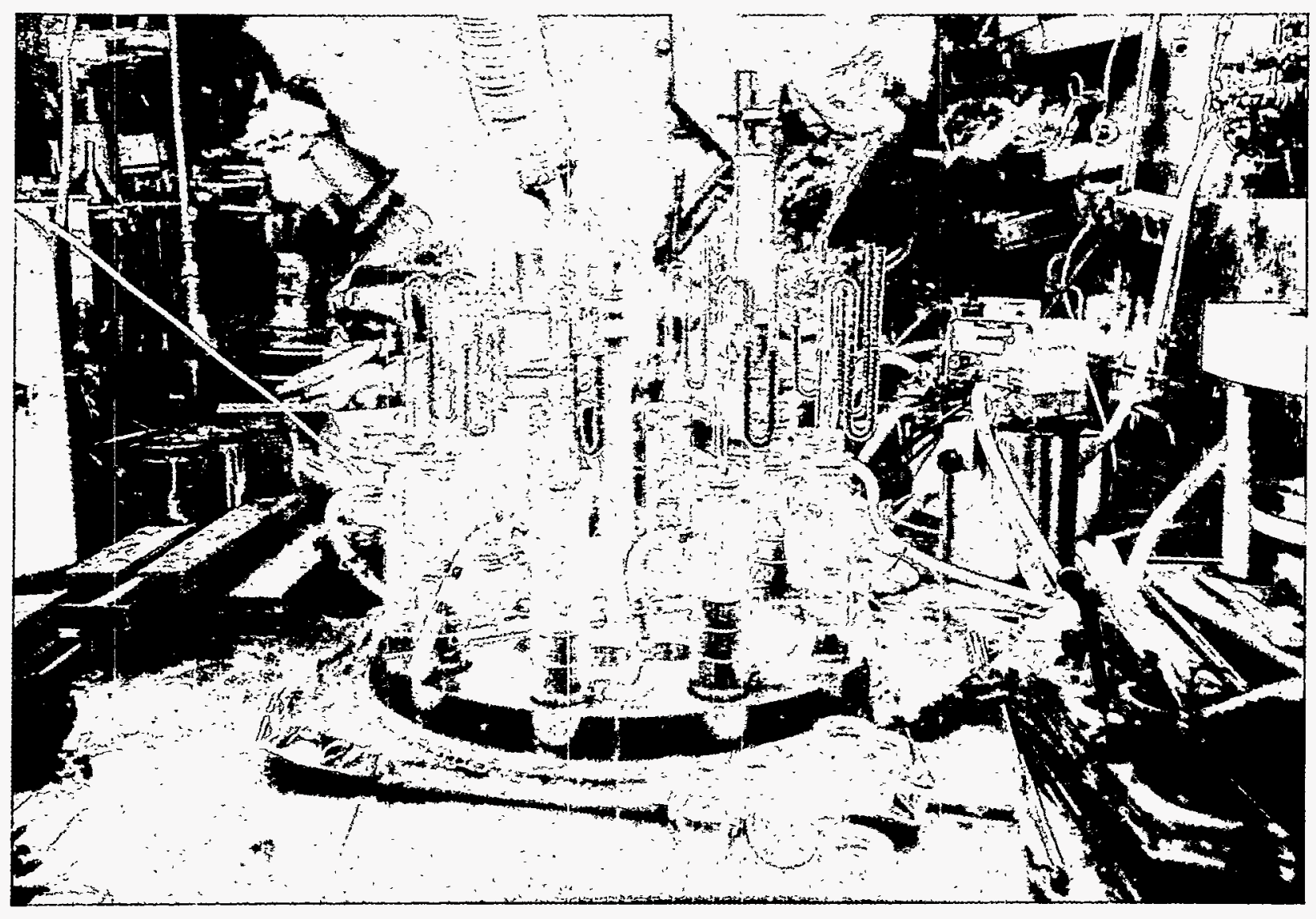

Figure 3.1. Gas-Retention Experiment in the Hot Cell 


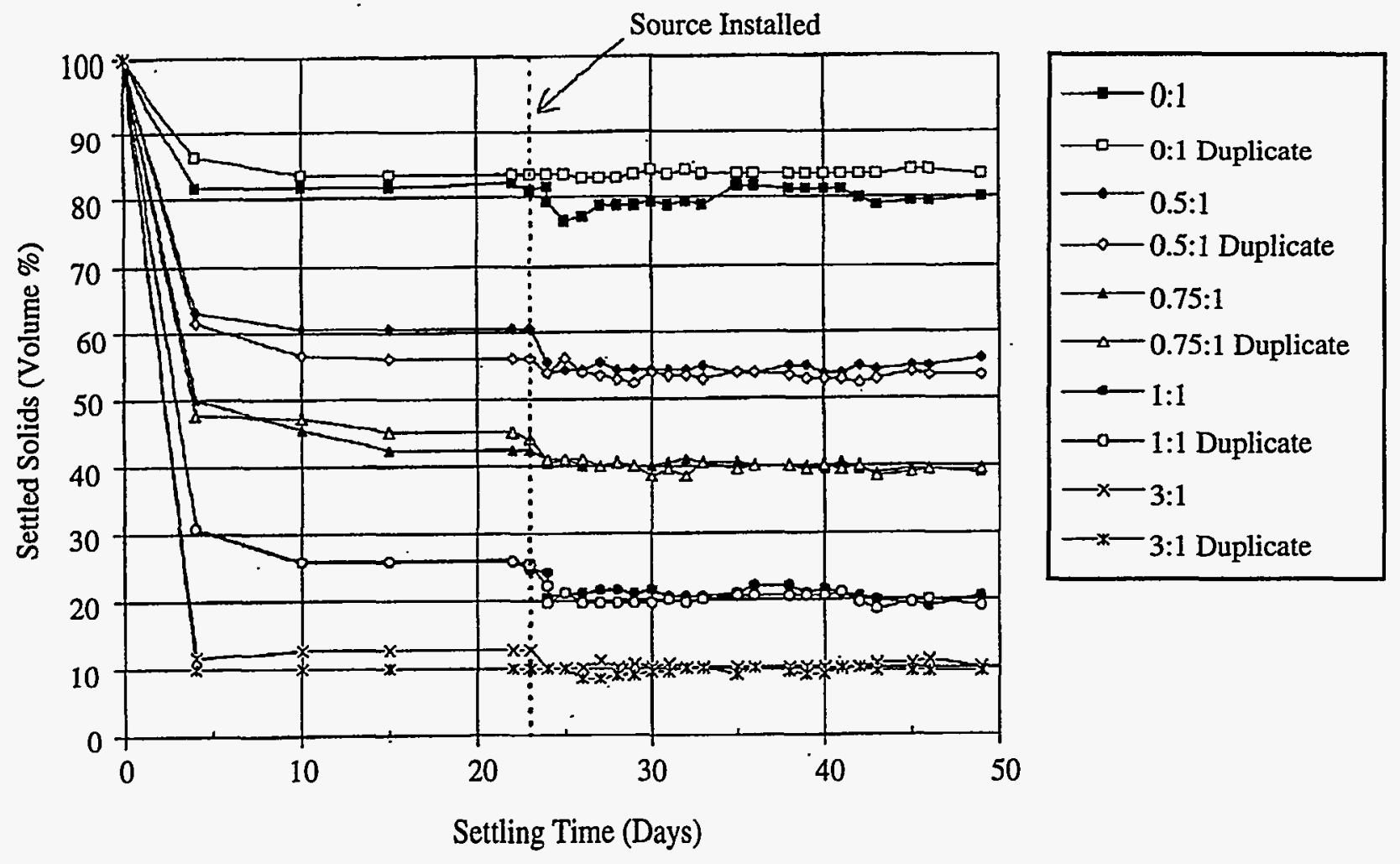

Figure 3.2. Volume Percent Settled Solids During the Settling and Irradiation Period

Table 3.2. Volume Percent Settled Solids at Day 23 and at End of Day 24

\begin{tabular}{|c|c|c|c|}
\hline Dilution & Day 23 & Day 24 & Decrease (\%) \\
\hline $0.00: 1$ & 81.0 & 79.3 & 2.1 \\
\hline 0.00:1 Dup & 83.3 & 83.3 & 0.0 \\
\hline $0.50: 1$ & 60.5 & 53.7 & 11.0 \\
\hline 0.50:1 Dup & 55.9 & 53.8 & 3.8 \\
\hline $0.75: 1$ & 42.5 & 40.5 & 4.7 \\
\hline 0.75:1 Dup & 44.1 & 41.0 & 7.0 \\
\hline $1: 00: 1$ & 24.6 & 20.5 & 17.0 \\
\hline 1.00:1 Dup & 25.3 & 19.6 & 23.0 \\
\hline $3.00: 1$ & 12.8 & 10.2 & 20.0 \\
\hline 3.00:1 Dup & 10.0 & 10.0 & 0.0 \\
\hline
\end{tabular}


The observed decrease in volume percent solids after placing the source in the rack may have been accompanied by an increase in shear strength. Previous work with SY-101 waste showed a decrease in viscosity and shear strength with increasing shear history ${ }^{(a)}$. This behavior is referred to as thixotropy. This observed decrease was not recovered after leaving the sample undisturbed for 2 years. This potential increase in shear strength was not further investigated because a study of the effects of radiation on the rheological properties of the waste was not included in the scope of work.

\subsection{Gas Generation and Retention}

The changes in total waste volumes are listed in Table 3.3. These data were calculated by averaging the five first and last measurements collected during the irradiation phase of the experiment. Table 3.3 and Figure 3.2 show no increase in the settled solids volume or total waste volume as a result of sample irradiation. The absence of settled solids growth could indicate no round bubble retention. However, as noted in Section 3.1; the solids experienced settling at the start of the irradiation phase of the experiment; and round bubble growth could have occurred without being observed as an increase in settled solids volume if settling continued during irradiation. The absence of growth in the total waste column indicates no retention regardless of bubble type, round or dendritic.

Table 3.3 shows a net drop in the waste volume as a result of evaporation of the supernate. The mercury manometers were designed to return any condensate to the sample vessels. However, drops of condensation were noted in the first vertical portion of the manometers. It is possible that evaporation could have obscured the gas-retention calculations by approximately $1 \mathrm{~mL}, 2 \%$ of the total waste volume.

Table 3.3. Total Waste Volumes From the Irradiation Phase of Testing

Total Waste Volame (mL)

\begin{tabular}{lllr} 
Dilution & Initial & Final & Change \\
\cline { 1 - 1 } $0.00: 1$ & 46.0 & 45.4 & -0.6 \\
$0.00: 1$ Dup & 46.2 & 46.6 & 0.4 \\
$0.50: 1$ & 48.4 & 47.5 & -0.9 \\
$0.50: 1$ Dup & 49.1 & 48.4 & -0.7 \\
$0.75: 1$ & 50.7 & 50.2 & -0.5 \\
$0.75: 1$ Dup & 48.7 & 48.9 & 0.2 \\
$1.00: 1$ & 49.6 & 48.4 & -1.2 \\
$1.00: 1$ Dup & 48.5 & 48.0 & -0.5 \\
$3.00: 1$ & 48.5 & 47.4 & -1.1 \\
$3.00: 1$ Dup & 50.7 & 49.5 & -1.3
\end{tabular}

(a) J.M. Tingey, February 1992. Physical Characterization of Tank 101-SY Core Samples from Window C. Letter report to Westinghouse Hanford Company. Pacific Northwest Laboratory, Richland, Washington. J.M. Tingey, May 1992. Rheological Properties of Waste From Tank 101-SY. Letter report to Westinghouse Hanford Company. Pacific Northwest Laboratory, Richland, Washington. 
The total gas-generation data are plotted in Figure 3.3 as an increase in volume from $115 \mathrm{~h}$ after the start of irradiation. This volume change has been corrected to 760 torr. The data have not been corrected for temperature because temperature gradients within the head space were not measured ${ }^{(a)}$. Data before $115 \mathrm{~h}$ showed a net loss of gas, most likely a result of oxygen consumption. Although a net gas loss is not seen after $115 \mathrm{~h}$, oxygen consumption would be expected to have continued throughout the irradiation phase and contributed to a lower measured total gas generation. In Figure 3.3 , a drop in gas volume is seen at $307 \mathrm{~h}$ into the irradiation. At this time, flow through the cell was increased by a factor of 1.7. It is likely that this increase in flow dropped the cell temperature enough to cause a contraction of the gas in the head space of the vessels. The ambient temperature in the cell was not monitored on a daily basis.

Figure 3.3 shows that the $0.5: 1$ and $0.75: 1$ diluted samples have a higher gas generation rate than the composite. No systematic errors could be found to explain this increase in gas generation, and significant changes were noted in the physical properties of the waste in this range during previous work (Tingey et al. 1994). Therefore, this observation is believed to be real. The 1:1 and 3:1 diluted samples experience similar gas generation behavior, below that of the composite.

\subsection{Applying Vacuum to the Sample Vessels}

After 27 days of irradiation at $2.5 \mathrm{kR} / \mathrm{h}(1.6 \times 106 \mathrm{R})$, no gas retention was observed. Several factors could have contributed to this observation: 1) Only $2 \mathrm{~mL}$ of gas were generated (in the $0.5: 1$ samples) during the irradiation period. This volume was lower than anticipated and could have been exceeded by volume changes resulting from collapses in the settled bed. 2) Gas formed in the solids could have diffused out. The vessels were $2.54 \mathrm{~cm}$ in diameter, so gas diffusing through the solids would only need to travel $1.27 \mathrm{~cm}$ to the walls where cracks running up the sides of the settled bed could carry it to the liquid layer. Diffusion was an anticipated problem; however, the experiment was restricted to $<60-\mathrm{mL}$ sample sizes by the practicality of in-cell work.

(a) The head space volume was approximately $47 \mathrm{~mL}, 20 \mathrm{~mL}$ in the water jacket at $50^{\circ} \mathrm{C}$ and $27 \mathrm{~mL}$ above the jacket exposed to an ambient temperature of approximately $33^{\circ} \mathrm{C}$. Since dilution should result in more gas released to the head space, a temperature correction could result in a relative increase in the gas generated by the more diluted samples. 


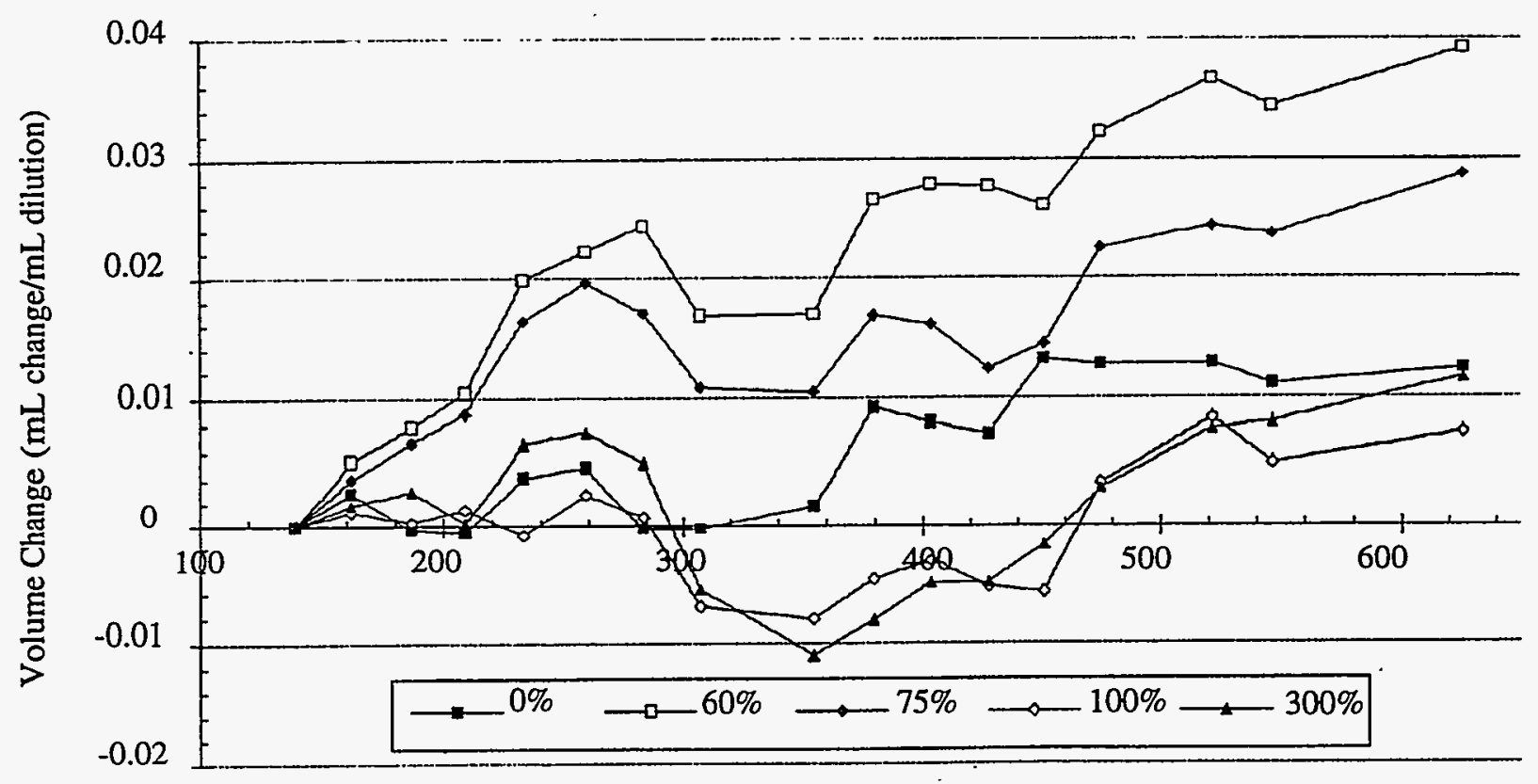

Irradiation Time (h)

Figure 3.3. Gas Generation Plotted as Volume Change in the Head Space of the Sample Vessels. These data have not been corrected for temperature differences between the vessel and manometer.

Two experimental conditions (shear history of the waste samples and small settled-bed heights) were anticipated to cause poor gas retention, but evacuation showed not to be a problem. The shear strength of SY-101 nonconvective layer waste is a factor contributing to gas-retention behavior. Previous work with SY-101 waste showed a decrease in shear strength with increasing shear history ${ }^{(a)}$. Some samples used to prepare the composite had been exposed to shearing forces on the order of $500 \mathrm{~s}-1$ during rheological analyses. It was anticipated that the shear history of the samples and the small bed height, resulting in less compaction of the settled solids layer, would reduce the shear strength of the settled solids layer to the point that gas bubbles would not be retained. However, as the following will show, the composite, $0.5: 1$, and $0.75: 1$ diluted samples possessed sufficient shear strength to retain gas bubbles.

It was decided that a vacuum should be applied to the head space of one sample at each of the dilution levels. In simulant studies, Rassat and Gauglitz (1995) showed that this technique could be used to expand existing bubbles and cause dissolved gases, primarily $\mathrm{NH}_{3}$ (Norton and Pederson 1994), to nucleate or further increase the size of existing bubbles.

The vacuum in this study was estimated to be $22 \mathrm{in.} \mathrm{of} \mathrm{mercury.} \mathrm{The} \mathrm{rate} \mathrm{at} \mathrm{which} \mathrm{the} \mathrm{vacuum}$ was applied to the head space was not accurately controlled. The vessels reached $22 \mathrm{in}$. of mercury within about $1 \mathrm{~min}$. Settled solids growth was observed in the composite, 0.5:1, 0.75:1, and 1:1 diluted samples, indicating round bubble growth. The total waste volume was monitored during evacuation of the composite and 0.5:1 diluted sample, and no dendritic bubble formation was observed. Bubbles were observed releasing from the solids at all dilution levels, including the 3:1 ratio, but no bubbles were observed nucleating in the liquid (supernate) layer.

(a) J.M. Tingey, February 1992. Physical Characterization of Tank 10I-SY Core Samples from Window C. Letter report to Westinghouse Hanford Company. Pacific Northwest Laboratory, Richland, Washington. J.M. Tingey, May 1992. Rheological Properties of Waste From Tank 101-SY. Letter report to Westinghouse Hanford Company. Pacific Northwest Laboratory, Richland, Washington. 
Upon application of the vacuum, the solids level in the composite grew by $17 \%( \pm 2 \%)$ and remained at that level for approximately $1 \mathrm{~min}$ before the solid cohesion was lost and the solid-gas mixture rose to the surface. The 0.5:1 diluted sample grew as the vacuum was applied. Before the full vacuum was reached, at $10 \%( \pm 3 \%)$ growth, the solid-gas mixture lost cohesion, and the solid-gas mixture sheared. Sixty percent of the solid-gas mixture rose to the surface. The settled solids in the 0.75:1 sample grew past buoyancy, separated from the vessel walls as a single mass, and rose to the surface. At the surface, the solid growth was measured at $8 \%( \pm 4)$. The solids level in the $1: 1$ sample increased by $18 \%( \pm 8 \%)$ as the vacuum was applied. Before full vacuum was reached, bubbles approximately $1 / 4 \mathrm{~cm}$ in diameter were observed releasing from the solids. The bubble releases continued for roughly $10 \mathrm{~min}$. No solids growth was noted in the 3:1 diluted sample.

The release events of the composite, $0.5: 1$, and 0.75:1 diluted samples followed behavior observed in actual tank rollovers. Large amounts of solids were involved in the release, the rise occurred throughout the vessels at the same time, the event was initiated by a yielding of the material, and the events were short in duration. The release in the 1:1 diluted sample was dominated by individual bubble releases and was slower by a factor of 10 . The bubbles in the $1: 1$ sample had very little interaction with the solids and were released through the solids. This result indicates that at a dilution level below 1:1, bubbles are formed and retained in the solids, and at levels of $\geq 1: 1$, bubbles are not retained in the solids. 


\subsection{Summary and Conclusions}

In this work, the effect of dilution on the ability of SY-101 waste to retain gas was investigated. Gas generation was highest for the $0.5: 1$ dilution ratio followed by $0.75: 1$ and then the tank composite. Gas generation at ratios of 1:1 and 3:1 were similar and below the generation in the tank composite.

Volume measurements taken during sample irradiation did not indicate significant gas retention in any of the samples; however, both solids settling and evaporation of supernate observed during sample irradiation could have obscured the measurement by as much as $1 \mathrm{~mL}$ of retained gas, $2 \%$ of the total waste volume.

Application of a vacuum to the head space of the vessels caused growth in the settled solids for all the samples except the 3:1 dilution ratio. The composite, $0.50: 1$, and $0.75: 1$ samples experienced gas retention and events similar to tank rollovers. The 1:1 sample released gas through the solids over an extended period without significantly disturbing the settled solids layer. Fewer gas bubbles were observed releasing from the 3:1 sample, and no growth was noted in the settled-solids layer. 



\subsection{References}

Babad, H., G.D. Johnson, J.A. Lechelt, D.A. Reynolds, L.A. Pederson, D.M. Strachan, D. Meisel, C.D. Jonah, and E.C. Ashby. 1991. Evaluation of the Generation and Release of Flammable Gases in Tank 241-SY-101. WHC-EP-0517, Westinghouse Hanford Company, Richland, Washington.

Gauglitz, P.A., and S.D. Rassat. 1995. Experimental Methods To Generate Retained Bubbles in Simulated Sludges. WTSFG95.10, Pacific Northwest Laboratory, Richland, Washington.

Glasrud, G.G., R.C. Navarrete, L.E. Sciven, and C.W. Macosko. 1993. "Settling Behaviors of Iron Oxide Suspensions," AIChE Journal, 39(4), 560.

Herting, D.L., D.B. Bechtold, B.A. Crawford, T.L Welsh and L. Jensen. 1992a. Laboratory Characterization of Samples Taken in May 1991 from Hanford Waste Tank 241-SY-101. WHC-SDWM-DRT-024 Rev.0, Westinghouse Hanford Company, Richland, Washington.

Herting, D.L., D.B. Bechtold, B.E. Hey, B.D. Keele, T.L. Welsh, and L. Jensen. 1992b. Laboratory Characterization of Samples Taken in December 1991 (Window E) From Hanford Waste Tank 241SY-101. WHC-SD-WM-DRT-026 Rev.0, Westinghouse Hanford Company, Richland, Washington.

Hudson, J.D., G.S. Barney, P.R. Bredt, A.R. Felmy, D.L. Herting, A.P. Larrick, D.A. Reynolds, C.W. Stewart, J.M. Tingey, and D.S. Trent. 1995. An Assessment of the Dilution Required to Mitigate Hanford Tank 241-SY-101. PNL-10417, Pacific Northwest Laboratory, Richland, Washington.

Norton, J.D., L.R. Pederson. 1994. Ammonia in Simulated Hanford Double-Shell Tank Wastes: Solubility and Effects on Surface Tension. PNL-10173, Pacific Northwest Laboratory, Richland, Washington

Rassat, S.D., and P.A. Gauglitz. 1995. Bubble Retention in Synthetic Sludge: Testing of Alternative Gas Retention Apparatus. PNL-10661. Pacific Northwest Laboratory, Richland, Washington.

Stewart, C.W., J.D. Hudson, J.R. Friley, F.E. Panisko, Z.I. Antoniak, T.E. Michener, J.G. Fadeff, L.F. Efferding, J.J. Irwin, N.W. Kirch, and D.A. Reynolds. 1994. Mitigation of Tank 241-SY-101 by Pump Mixing: Results of Full-Scale Testing. PNL-9959, Pacific Northwest Laboratory, Richland, Washington.

Stewart, C.W., L.A. Schienbein, J.D. Hudson, E.J. Eschbach, and D.L. Lessor. 1994. Assessment of Alternate Mitigation Concepts for Hanford Flammable Gas Tanks. PNL-10105, Pacific Northwest Laboratory, Richland, Washington.

Tingey, J.M., P.R. Bredt, and E.H. Shade. 1994. The Effects of Heating and Dilution On the Rheological and Physical Properties of Tank 241-SY-101 Waste. PNL-10198, Pacific Northwest Laboratory, Richland, Washington. 


\section{Distribution}

No. of

Copies

Offsite

2 DOE/Office of Scientific and Technical Information

K. Pasamehmetoglu

TSA-6/K-55

Los Alamos National Laboratory

Los Alamos, New Mexico

Onsite

DOE Richland Operations Office

J.M. Gray

C.A. Groendyke

G.W. Rosenwald

5 Westinghouse Hanford Company

T.R. Benegas

C.E. Hanson

G.D. Johnson

J.W. Lentsch

E.J. Lipke

N.G. McDuffie

C.A. Reick

D.A. Reynolds

J.E. Van Beek
No. of

Copies

Onsite

27 Pacific Northwest Laboratory

J.M. Bates

P.R. Bredt (10)

J.W. Brothers

P.A. Gauglitz

J.D. Hudson (5)

F.E. Panisko

C.W. Stewart

J.M. Tingey

S.M. Tingey

Technical Report Files (5)

Dist. 1 